\title{
O NEGRO NO RIO GRANDE DO SUL*
}

Dante de Laytano**

\section{PRIMEIRA PARTE - ASPECTO DEMOGRÁFICO} Brasil?

Como encontrar as origens da entrada do negro no extremo sul do

Existiram ou não negros nas bandeiras paulistas que penetraram no Rio Grande?

As palavras - "negro" e "negra" significarão africano? O que nos garante? Qual a autoridade para isso nos asseverar? "A interpretação de que estas palavras significam ameríndios está evidente", escreve Alfredo Elis Júnior, referindo-se ao estudo da palavras "negro" e "negra" nos documentos da época bandeirante, em seu "Resumo da História de São Paulo (Quinhentismo e Seiscentismo)".

Se há dúvida com a interpretação das palavras negro e negra, o que dizer do termo escravo? Escravo índio ou escravo africano? Quando nas peças, documentos, inventários e testamentos e atos encontramos apenas a palavra escravo? Taunay e Teschauer não fazem, como quase todos os historiadores do assunto, referência à existência de africanos nas bandeiras. O pesquisador poderá somente usar documentos precisos, se está realmente interessado em não aumentar a confusão reinante.

\footnotetext{
* Trabalho apresentado no I Seminário de Cultura Gaúcha. Porto Alegre, RS. 1957. ** Prof. Emérito da PUCRS
} 


\section{I-Silva Paes - 1737}

No "Indice da Correspondência dos Governadores do Rio de Janeiro com diversas autoridades" (1718-1763), in "Publicaçôes do Arquivo Nacional", vol. VIII, notamos, na correspondência recebida pelo governador Gomes Freire de Andrade, umir carta enviada, em 12 de abril de 1737, pelo Brigadeiro da Silva Paes, do Rio Grande, nesse mesmo ano que ele inaugurava os fundamentos de nova cidade, ponto de partida para o povoamento da futura capitania de Sáo Pedro.

A carta de Silva Paes a Gomes Freire é fazendo sentir que existiam moradores desejosos de se estabelecerem no Rio Grande (onde apenas se cogitara de fortificaçôes e um presídio militar) e que naturalmente a maioria desses moradores era composta de tesidentes portugueses na Colônia do Sacramento; sugeria o fundador do Rio Grande auxilios aos novos povoadores, principalmente na "ida dos escravos dos moradores para lá (Rio Grande) sem pagarem dircitos".

Apenas no terceiro més de posse sistemática e efetiva do Rio Grande, jấ temos informes da presença de escravos pretos nestas novas terras.

\section{II-Ribeiro Coutinho - 1738}

Ao terminar o ano de 1738, entre as cartas que o Governador do Rio de Janeiro, de quem dependia a administraçáo do sul do Brasil, endereçava ao mestre de campo André Ribeiro Coutinho, governador do Rio Grande e comandante das tropas, consta uma sobre "escravo fugido do capitão Fernando $\mathrm{C}$. de Melo" e é bem cedo, para somente um ano de povoamento oficial, registrar-se um fato dessi natureza; a outra carta 6 remetendo "soldados, escravos e dinheiro".

Temos, assim, alguns esclarecimentos sobre a vinda contínua do elemento negro, aliado indispensível do colonizador.

Afinal com soldados, escravos e dinheiro poder-se-ia realizar alguma coisa estável e segura em matéria de povormento.

No ano seguinte da fundaçăo do presidio no Rio Grande, com que se marca o início da colonizaçăo dessa regiáo do Sul do Brasil, na correspondència entre Silva Paes e Gomes Freire (entáo governador do Rio de Janeiro, Minas e São Paulo) que andava pelas Minas Gerais, sabe se da "prisăo de soldados por terem roubado uma negra", 
Nîto é a prisīo de um soldado, mas de soldados.

A súmula de correspondência nẫo dìz o que os soĺdados roubaram da negra, evidentemente porque o próprio original disso nāo trata, mas o fato que a pena imposta foi severa, respeitando-se au mandando que se respeitasse mesmo as posses de uma negra, posses que deveriam ser infimas.

\section{III - José da Veiga - 1740}

Através de um termo de arremataçăo de contrata de escravos feito em 1740, trểs anos depois da colonizaçâo oficial do Rio Grande do Sul, lê-se que a certo José Ferreira da Veiga, entāo o arrematante, obrigava-se por lei, a pagar direitos para todos os escrawos "que forem para Rio Grande e Ilha de Santa Catarima (pelos quais antes se dava fiança)".

Fsse José Ferreira da Veiga desejavia e obteve mesmo que a entrada de escravos para toda e qualquer parte do Brasil año fosse mediante fiança, mas, sim, por pagamento de direitos. No despacho da ordem que se expedia a um Domingos Roiz Bandeira ficou figutando que seria feito o pagamento de direitos "nẩo só dos escravos que fossem para Miaas, mas também os que foosem para Parati, Iha Grande, Paranagui, Santos; São Paulo".

O Governo despachou um contrato de venda de escravos obtido para o centro do país por tal Roiz, tendo logo $\mathrm{cm}$ vista a ordem conseguida por Ferreira da Veiga para o Rio Grande.

\section{IV - Livros de Batismo de Viamăo - 1747}

"Os africanos que batizanam filhos no Viamão (um dos primeiros núcleos de povoamento do Rio Grande do Sul) eram naturais de Costa de Mina, Cabo Verde, Angola, Guiné e Congo" segundo Aurélio Porto no seu divulgado "Dicionário Enciclopédico do Rio Girande do Sal". Obra que infelizmente ficou no terceiro fasciculo.

Referiil-se ele aos afficanos que batizaram filhos no Viamāo, porque compulsou as livros de batismo de 1747 a 1758 , verificando 350 batizados ao todo, discriminados assim: 308 brancos, 21 indios, 21 pretos. Mas os indios e os africanos teriam butizado sempre seus filhos? 
Ou o pequeno elī se permitiria o que é mais lógico, a uma vida sem os rigores da Igreja?

\section{V-Gomes Freire - 1751}

Na verdade, por alvurí de 1751, colecioaado no "Index" citado, estabelecia-se 'que nià possum passar negros dos Portos de Mar para terras que não sejam dos Domínios Portugueses: que se não dé despachos a Escravos para a Colönia do Sacramento, ou outros lugares vizinhos à Raia Portuguesa, sem que fiquem afiançados nas provedorias desta cidade do Rio de Janciro, ou Bahia relaçōes dos Escravos, que nagueles lugares entraram, con declaraçāo dos que morreram, ou faltaram para causa justa, ou por passarem por terras dos mesmos Domínios Portugueses",

Com a colónia do Sacramento ao lado do Rio Grande, o problema de contrabando de escravos se ia agravando cada vez mais.

As medidas de repressảo procuraram sanar o mal para os cofres da coroa, mas em verdade ể novvo contigente humano de procedência africana que se tem de incluir entre a populaçáo meridional do Brasil, ou melhor, do Rio Grande do Sal, vindo por intermédio do Rio da Prata...

No "Index da Correspondència da Corte de Portugal com os ViceReis do Brasil no Rio de Janeiro" (de 1763 a 1807), que aparece como matéria do vol. III das "Publicaçôes do Arquuivo Nacional" deparamos com duas medidas que as autoridades de Lisboa ordenaram aos representantes no Brasil e que interessam ao problema do homem negro: uma dessas ordens diza respeito à proibição da passagem de escravos para o dominio espanhol e mandando executar as disposiçóes que vedam este comércio, e outra providenciava na diminuiçâo do consumo da cachaça nos portos do Brasil e ao mesmo tempo que cuidava do aumento da sua exportação para a África.

A proibiço da passagem de escrayos para os dominios da Espanha, as fronteiras do sul, estava sendo levada a sério pelo governo desde muito, bem como do comércio de cachaça, como se verá em 1798, ao tempo do Conde de Rezende.

Naturalmente era isso, nấo só para impedir os prejuizos do erário português, como para também proteger a agricultura no sul que facilmente era trocada, por menos trabalhosa e de major lucro, pela criação de gido. 


\section{VI - Custódio de Sá e Faria - 1767}

O Governador José Custódio de Sá e Faria, numa carta de 28 de maio de 1767, enviada ao Cel. José Marcelino de Figueiredo, sobre o ataque do Rio Grande, queixava-se da falta de cumprimento dos tratados da fronteira por parte dos espanhóis e dizia: "Fazendo-se acla fronteira as bostilidades que sấo notórias, nāo querendo restimir-nos o grande número de pretos escravos que băo passado a sua parte, havendo-se reclamado repetidas vezes, e respondendo o dito Comandante D. José de Molina a serviço de Madrid ser ato mai próprio da Soberania dos Reis admitir os ditos escravos, que fogem da Escravidão, como consta da Carta do dito de primeiro de outubro de 1765".

"Hostilidade feita aos Vassalos del Rey N. St. que tem experimentado tăo grave prejuízo na falta dos ditos escravos..." acrescenta o governador.

\section{VII - Aurélio Porto e o mapa do Tenente Córdova - 1780}

O mapa esfatistico de 1780 do Tenente Córdova é o primeiro tecenseamento que se conhece do Rio Grande do Sul.

Aurélio Pôrto, investigndor realmente seguro, a quen se devem as pesquisas mais interessantes sobre a parte meridional da América Portuguesa, diz que do mupa do Tenente Córdova se pode fazer a seguinte conclusão: em cada 1.000 habitantes: 526 brancos, 285 pretos, 189 indios.

No mapa nắo se avalia o número de indigenase o comentador, tendo em vista dados geogríficos e históricos, faz uma recomposiçâo muito natural e razoavelmente próxima da realidade.

Mas o que nos interessa ó o homem afrícano e o apreciaremos através do mapa do Tenente Córdova, adaptado pelo historiador Aurélio Porto.

Pelo quadro $s e$ podem ver localidades com a populaçấo preta imensamente maior do que a branca e outros centros, em que o numero de pretos quase alcança ao de brancos.

Toda a populaçâo do Rio Grande do Sul se computava em 1780 em 17.923 thabitantes, distribuidos da seguinte maneira: Madre de Deus, 1.512; Estreito, 1.254; Mostardas, 591; Viamão, 1.891; Santo Antônio, 1.189; Conceiçăo do Artoio, 417; Aldeia dos Anjos, 2.355; Vacaria, 571; 
Triunfo, 1.277; Taquari, 689; Santo Amaro, 720 e Cachocira, 662; Rio Grande, 2.421; Rio Pardo, 2374.

O quadro do Tenente Córdova, que foi recomposto pelo escritor Aurélio Porto é o seguinte:

\begin{tabular}{|l|r|r|r|r|}
\hline Freguesias & Brancos & Indios & Pretos & \multicolumn{1}{c|}{ Total } \\
\hline Maudre de Deus & 871 & 96 & 545 & 1.512 \\
\hline Rio Grande & 1.643 & 182 & 596 & 2.421 \\
\hline Estreito & 880 & 97 & 277 & 1.254 \\
\hline Mostardas & 360 & 40 & 191 & 591 \\
\hline Vianiäo & 1.028 & 114 & 749 & 1.891 \\
\hline St ${ }^{0}$ Antônio & 828 & 91 & 270 & 1.189 \\
\hline Conc do Arroio & 234 & 25 & 158 & 417 \\
\hline Aldeia dos Arjos & 210 & 1.890 & 255 & 2.355 \\
\hline Vacaria & 291 & 32 & 248 & 571 \\
\hline Triunfo & 637 & - & 640 & 1.277 \\
\hline Taquari & 580 & - & 109 & 689 \\
\hline St ${ }^{2}$ Amaro & 512 & - & 208 & 720 \\
\hline Rio Pardo & 1.317 & 438 & 619 & 2.374 \\
\hline Cachocira & 42 & 383 & 237 & 662 \\
\hline Totais & 9.433 & 3.388 & 5.102 & 17.923 \\
\hline
\end{tabular}

\section{VIII - Conde de Rezende - 1798}

A fiança substituida pelo pagamento de direitos parece que marcou o inicio de cntradas de negros auma escala muito major no Rio Grande do Sul.

Esta ordem sobre escravos obxida para o extremo sul do Brasil e depois estendida para o resto do território consta do "Index Alfabético de Lei Alvarás, cartas Régias, Dectetos, e mais ordents que há no arquivo 
da Provedoria da Fazenda Real". Feito por determinaçăo do Vice-Rei do Brasil (n. XXI - Pub. Arq. Nacional - 1923).

Temos mais uma informaçăo oficial sobre a existência de negros no sul durante o século XVIII, e existênecia bem significativa para mover a corte portuguesa a uma providếncia enèrgica que não poderia sèt medida apenas burocrática, quando ainda deveria se ter em vista que o caso envolvia delicado assunto de fronteiras com os domínios de Espanha. Além das medidas de repressăo do contrabando, também outras sobre o controle do negócio da cachaça.

É do ano de 1798 , essia pitoresca determinaçăo das autoridades sobre a cachaça nos portos do Brasil, cachaça que fazia năo só o regalo dos pretos, como pretende a determinaçăo mas do índio, de muita gente branca e até aristocrática.

Mas o impedimento do consumo da cachaça seria uma maneira de combater a vadiagem no Brasil. Pensava o governo, que ao lado de outras medidas para resolver o caso, lançava-se a proibiçálo do uso da cachaça nos portos; o interior estava fora dessa lei anti-aleoćlica, interior do Brasil e a África; a África, sim, poderia usar e abusar da cachaça, a África Portuguesa ficava apta a receler entio melhor os mercadores de escravos.

Era o $5^{\circ}$ Vice-Rei do Brasil D. José de Castro, Conde de Rezende.

\section{IX-Paulo Gama-1804}

Paulo da Silva Gama, chefe de esquadra, que governou o Rio Grande do Sul, temetia em 5 de dezembro de 1804 ao Visoonde de Ansdia um interessante quadro estatístico sobre a capitania, onde se dizia "que nīo tinham entrado na apreciaçấo o número de tropa đe linha e os que não chegaram a ano de idade; este mapa é tirado pelos assentos da freguesias, porém os melhores práticos desta campanha me asseguraram haver para cima quatro mil homens que andam no campo pelas charqueadas, sem domicilio certo, o que por este motivo nāo tem assento em freguesia alguma...".

Os centros de maior populaçấ, em 1804, eram no Rio Grande do Sul: Săo Pedro do Rio Grande com 8.390 habitantes, Porlo Alcgre com 3.927 e Rio Pardo com 3.739.

A populaçăo de toda a Capitaniat tinhat entî́o 36.721 habitantes. 


\section{$X-D$. Diogo de Sousa - 1811}

Lendo os mapas dos vigários das freguesias da Conceiçăo do Estreito, S. Pedro do Rio Grande c Mostardas, que Joaquim Felix da Fonseca encarninhava a D. Diogo de Sousa, governador e capitẫo-general do Rio Grande, em 1811, achamos o seguinte, como for pablicado na "Revista do Arquivo Público do Rio Grande do Sul":

Freguesia N. Sra. da Conceiçăo do Estreito - Pretos - 631. M. 394 eF. 371. - Forros - 151. Pretos 21 e Pardos 130. Brancos 795.

Freguesia de S. Pedro da Vila do Rio Grande - Pretos - 2.796. M. 2.077 eF. 719, - Forros - 354. Pretos - 95 e Pardos 259. Brancos 7.162

Freguesia de S. Luís de Mostardas-Pretos 367 M. 243 e F. 121. Forros - 110. Pretos 32 e. Pardos 78. Brancos 775.

\section{$\mathrm{XI}$ - Último recenseamento colonial - 1814}

No ültimo recenseamento colonial, de que se tem conhecimento, $\alpha$ Rio Grande estif com 70.656 habitantes, dos quais 32,300 sân brancos, 8.655 indios, 5.399 livres de todas as cores, 20.611 escravos de ambos os sexes e 3.691 recím-nascides.

Observa-se a distinçẫo entre escravos e indigenas, o que não deixa de ser importante, pois os escravos que se mencionam aqui sío negros, somente, pois os indigenas tinham obtido sua liberdade.

E os livres de todas as cores? Quanto seriam os negros e mulatos?

O levantimento se processou minuciosamente, como ef ficil nota em Conceiçio do Arroio, por exemplo: Brancos de ambos os sexos 837 , indigenas 19 , livres de todas as cores 180 , escravos 538 , recém-nascidos 74 , total 1.648 .

Foram recenseadas quinze regiōes, e, sem estrar em maiores detathes, assinalaremos que $\mathrm{em}$ Viamăo com 1.545 brancos de ambos os sexcs existiam 908 escravos, Santo Antônio 1.706 e 961, Mostardas 723 e 281, Nossa Senhora dos Anjos 1.292 e 716, Porto Alegre 2.746 e 2.312, Triunfo 1.760 e 1.208 , Santo Amaro 953 e 773 , Taquari 1.092 e 433, Rio Pardo 5.931 e 2.429, Cachoeira 4.576 e 2.622 , Piratini 1.439 e 1.535 , Pelotas 712 e 1.226, Rio Grande 2.047 e 1.119 e Missóes 824 e 252.

Vè-se que $\mathrm{em}$ Pelotas e Piratini a populaçăo escrava negra é superior a branca e que Porto Alegre o Santo Amaro quase se igualam. Noutras localidades, como se notou, deveras expressiva, eom exceção 
das Missōes, a percentagem da populaçăo indígena está mutito abaixo, em número, da negra.

Excluindo-se us livres de todas as cores e os recém-nisscidos, onde devem ser incluídos negros e seus mestiços, a populaçắo preta é de perto de $35 \%$ comparada com a branca.

Indice bem valioso para os que negam a influência negra no Rio Grande do Sul.

O censo de 1814, que aparece no "Quadro Estatístico e Geográfico" de Eleutério Camargo, engenheiro da Provincia, e que foi organizado "emt virtude de ordem do Exmo. St. Dr. Francisco Ignácio Marcondes Homem de Melo", presidente do Rio Grande do Sul, dava para Rio Pardo 10.445 habitantes, divididos em 5.931 brancos de ambos os sexos, 969 livres de todas as cores, 2.449 escravos de todas as cores, 289 recém-nascidos, também de todas as cores.

A população de Rio Pardo era a maior de todo o Rio Grande do Sul, scguindo-se-lhe Cachoeira com 8.225, Porto Alegre com 6.111 e a cidade de Rio Grande com $3.5 \%$ habitantes.

Porto Alegre, onde a populaçío chegava a 2.746 , a de escrayos era de 2.312 escravos negros.

Em Pelotas, entretanto onde a populaçầo branca era de 712 pessoas, num total de 2.419 , os escravos atingiam a 1.226 , ultrapassando aos brancos.

Noutras cidades brancos e escravos negros quase eram em mesmo númeto: Triunfo: 1.760 brancos e 1.208 escravos pretos; Santo Amaro: 953 brancos e 773 escrivos pretos.

Mas, recapitulando năo somente Pelotas tinha uma populaçăo negra que ultrapassava à branca: Piratini, também, possuía 1.439 brancos e 1.535 escravos negros.

\section{XII - O negro no tempo do império - 1848, 1858, 1859, 1860,1861}

Num "Quadro da população de 1848 pelas listas eclesiásticas" do Rio Grande do Sul, pode-se ver bem o nûmero de casamentos, batismos, e óbitos, libertos e escravos, número mais elevado de óbitos, menor de batismo e ainda menor de casamentos, ou porque os casamentos de escravos náo iam a registro eclesíástico (faziam-se atrás da igreja, como o povo diz quando quer se referir aos casamentos ilcgais) ou os batismos 
de escravos nầo intetessavam à sociedade da época. O fato é o mesmo quanto aos óbitos. A mortandade entre os pretos era surpreendente.

Foram preenchidas essas listus celesiásticus de $1848 \mathrm{em}$ cinqüenta e nove paróquias ou das que estavam em seu lugar, curatos, capelas, ete.

Em Porto Alegre: Nossa Senhora da Madre de Deus registrava os óbitos de 176 escravos e de 202 livres e libertos, os batismos de 203 escravos e 280 livres e libertos, os casimentos de 59 livres e 2 escravos e 97 de livres e libertos, 234 batismos de escravos e 186 livres e libertos, 35 casamentos de livres, 2 de libertos e 2 de escravos.

Sáo os dados da capital da provincia e evidentemente será fastidioso trazer aqui detalhes estatísticos que revelassem até o ambiente religioso do Rio Grande do Sul no ano de 1848 , ambiente que se estende a outros aspectos.

A populaçăo era calculada em 187.082; os casamentos foram os seguintes: 1.217 de livres, 53 de libertos, 38 de escravos (1.328 casamentos): batismos, 3.197 masculinos de livres e libertos, 3.019 femininos de livres e libertos, 1.161 masculinos de escravos, 1.138 femininos de escravos, ( 8.513 batismos); óbitos: 834 livres e libertos mascalinos, 662 livres e lilertos femininos, 573 escravos e 424 escravas (2.493 öbitos).

A "populaçî́o da província no fim do ano de 1858 , segundo o mapa tirado pelas listas de familia" dava no Rio Grande do Sul 71.911 escravos, 208.044 livres, 5.489 libertos, numa população geral de 285.444 .

Se năo encontramos localidades com a população negra escrava ultrapassando à população branca livre, excluindo-se os libertos, gente africana, temos diversos centros urbanos onde as duas populaçổes praticamente se igualam no número, embora cm certes distritos de alguns municipios a popalaçăo escrava africana é realmente maior do que a branca ou livre.

O quadro estatístico de 1858 foi levantado por distritos $\mathrm{c} \mathrm{cm}$ Pelotas, Rio Pardo e Arroio Grande, onde a populaçāo negra escrava é muior que a populaçấo de livres e libertos; em outros distritos as populaçóes africanas e branca e livre quase são do mesmo número, como em Encruzilhada, Caçapava, Pedras Brancas, Taim, Piratini, Estreito, Charqueadas, Herval, eic.

Nouiros distritos, negros escrayos constituem mais ou menos cinqûenta por cento da populaçảo comu em Porto Alegre, Viamão, Barra, Santo Amaro, Santana, Triunto, Caí, Siao Jerónimo, Boqueiriono, Cerro do Roque, Dores de Camaquil, Palnares, Herval, São José do Patrocinio, Cachoeira, Irapuá, Formigueiro, Lavras, Bagé, Canguçu, Jaguarāo, etc. 
Outros distritos tển apreciável, embora pequeno número de escravos africanos: São Gabriel, Santo Antônio da Patrulha, Conceição do Arroio, São Francisco de Paula, Lagoa Vermelha, Vacaria, Alegrete, Jaguarão, etc.

Somente a primitiva regiāo das missōes dos indios conserva um ínfimo número de escravos, năo acontecendo com as fronteiras, centro e litoral oade a indústria $e$ a lavoura do luso-brasileiro estavam a exigit bruços, que foram supridos pelos negros.

José dos Santos Pereira, "encarregado da estatística" do Rio Grande do Sul, organizou, dez anos depois (1858), um "rmapa estatistico da populaçāo da província classificada por idades, sexos, estados e condifôes com o resumo total de livres, libertos e escravos"; esse mapa ficou pronto em $1^{\circ}$ de outubro de 1859.

As regiōes, cujas estatisticas foram levantadas, ficaram agrupadas por comatcas.

A divisầo judiciária compreendia dez comarcas ao todo no Rio Grande do Sul e cada comaren com diversos municípios e o número de africanos é o seguinte:

Na comarca de Porto Alegre; em Porto Alegre, propriamente: 4.556 escravos e 3.861 escravas ( 8.517 numa populaçăo de 29.725 habitantes, contando perto de 1.000 libertos); Sảo Leopoldo: 1.097 escravos e 707 escravas (1.804 numa populaçio de 18.690, incluindo-se 114 libertos); Taquari: 1.533 escravos e 1.168 escravas (2.701 numa populaçio de 9.932 babitantes com 236 libertos); Triunfo: 1.591 escravos e 1.243 eseravas ( 2.834 numa populaçín de $9.531 \mathrm{com} 176$ tibertos).

Passamos aos outros municípios de diversas comarcas.

Santo Antônio: 2.999 escravos numa populaçăo de 14.930 habitantes; Conceiḉx́o do Artoio: 2.055 escravos sobre uma populaçăo de 8.636 ; Rio Pardo: numa população de 7.028 existiam 2.174 escravos; EncruziThada: numa populaçio de 6.180 existiam: 2.238 escravos; Cachocira: numa populaçito de 5.169 cxistiam 1.628 escravos; acrescenta-se que Rio Pardo, Encruzilhada e Cachoeira tinham 205, 60 e 85 libertos, respectivamente, para aumentarmos o número de gente africana no Rio Grande do Sul.

Em Caçapaya: 3.000 escravos e 256 libertos numa populaçäo de 10.076 habitantes; em Säo Gabriel: 2.046 escravos e 324 libertos numa população de 7.979 habitantes; em Santi Maria: 966 escravos c 20 libertos numa populaçî̃o de 5.110 habitantes: $\mathrm{cm}$ Bagé: 4.016 escravos e 344 libertos numa populaçắo de 12.312 habitantes. 
Alegrete: com 10.999 habitantes; 2.525 sáo escravos e 209 libertos; Uruguaiana: com 8.645 habitantes; 1.873 são escravos e 179 libertos.

Piratini tinha uma populaçấo de 8.634 habitantes com 3.154 escravos e 2.5 libertos; Cangıçu: 7.429 com 2.453 escravos e 175 libestos; Jaguarăo: 12.999 habitantes com 5.056 escravos e libertos.

Rio Grande, o municipio, com 4.369 escravos e 71 libertos numa populaçío de 19.882; São Joś do Norte: 1.082 escravos e 166 libertos muma populaç̆̃o đe 12.893 habitantes.

Cruz Alta, Passo Fundo, São Borja e Itaqui, que formaram os municipios de duas comarcas distintas, também estăo incluídos nesse mapa de José dos Santos Pereira, mas os índices colhidos sảo tào sem importância que nós dispensamos de trazê-los aqui.

Săo esses municipios da citada regiăo habitada pelos descendentes dos índios e mesmo de indios legitimos.

A populaçio da província do Rio Grande do Sul em 1858 é de 282.547 habitanies, inclusive 70.880 esctavos e 5.413 libertos.

Seria nos estender em demasia se comentássemos esse quadro estatístico ou pelo menos fizéssemos referéncias aos sexos e às idades: mas de qualquer maneira nāo deve passar desapercebida a quantidade elevada de escravos existentes desde a idade de cinco anos, dez, quinze, vinte e cinco, trinta e trinta e cinco, quarenta, somente começam a declinar os números depois de quarenta e cinco anos, e até muita gente velha de oitenta e cento $c$ tantos anos de idade.

Hấ ainda do citado ano, 1858, a do mesmo funcionário, outro quadro estatistico, agora sobre casamentos, batismos e óbitos de livres e escravos no Rio Grande do Sul, sempre, entretanto, muita escassez de elementos no tocante aos casamentos de escravos, mas muito precisos nos números do obituário e batizados.

Quanto acs escravos; 94 casamentos, 3.684 batizados e 1.684 obitos. Quanto aos livres, a fim de compararem-se os dados: 2.602 casamentos, 13.600 batizados e 3.698 óbitos.

O quadro correspondente ao filtimo semestre de 1858 e todo o ano de 1859.

No ano seguinte, 1860 , a populaçấ do Rio Grande do Sul, segundo calculos efetuados, aumentara de 13.381 pessoas, total no qual se inclúa para mais de 3.000 escravos através das listas de batísmo e uns poucos entrados pelo único porto marítimo. 
Em 1861, a populaçáo do Rio Grande do Sul se compōe de 370.446 habitantes dos quais 294.337 săo livves e libertos e 76.109 sấo escravos. Em 1863 o número de escravos passa para 77.419 auma populaçăo de 392.725 almas.

\section{XIII - Estatísticas atuais}

a) Populaçâo de fato do Estado do Rio Grande do Sul por municipios, segundo a cor, 1.IX.1940.

O número de pretos e pardos distribui-se, pelos municípios, da seguinte mancira e ordem:

Porto Alegre: Pretos - 19.411 e Pardos - 24.145. Total 43.556.

Municípios com mais de 10.000 pretos e pandos:

$1^{2}-$ Pelotas $(15.581)$

$2^{\circ}$ - Cachoeira $(13,157)$

$3^{2}-$ Bagé $(11.899)$

Municipios de mencs de 10.000 até 5,000 pretos e pardos:

$1^{2}-\mathrm{S}$. Gabriel (8.908)

$2^{4}$ - Santo António (8.774)

\begin{tabular}{|c|c|c|c|c|}
\hline \multirow{2}{*}{$\begin{array}{l}\text { Zonas Fisiogr. } \\
\text { e Municipios }\end{array}$} & \multicolumn{2}{|c|}{ Pretos } & \multicolumn{2}{|c|}{ Pardiss } \\
\hline & Homens & Mulheres & Homens & Mulheres \\
\hline Erechim & 1.118 & 1.073 & 1.688 & 1.605 \\
\hline Getúlio Vargis & 527 & 567 & 183 & 173 \\
\hline Marcelino Ramos & 235 & 201 & 150 & 137 \\
\hline Passo Fundo & 1.385 & 1.502 & 2.439 & 2.422 \\
\hline Z. das Ser, do Sudoeste & 11.449 & 11.524 & 6.750 & 6.913 \\
\hline Caçapa do Sul & 2.266 & 2317 & 809 & 9SB \\
\hline Canguçu & 2.968 & 2.989 & 1.506 & 1394 \\
\hline Encruzilhada do Sul & 2.078 & 2.204 & 2.130 & 2.327 \\
\hline Erval & 526 & 512 & 281 & 262 \\
\hline Lavras do Sul & 754 & 744 & 760 & 786 \\
\hline Pinheiro Machado & 928 & 936 & 695 & 707 \\
\hline Piratini & 1.929 & 1.822 & 479 & 479 \\
\hline
\end{tabular}




\begin{tabular}{|c|c|c|c|c|}
\hline \multirow{2}{*}{$\begin{array}{l}\text { Zonas Fisiogr. } \\
\text { e Municipios }\end{array}$} & \multicolumn{2}{|c|}{ Pretos: } & \multicolumn{2}{|c|}{ Pardos } \\
\hline & Homens & Mulheres & Homens & Mulheres \\
\hline Z. dos Camp. do Centro & 4.196 & 4.232 & 6.871 & 6.755 \\
\hline Cruz Alta & 971 & 1.141 & 1.479 & 1.587 \\
\hline Júlio de Castilhos & 524 & 466 & 1.135 & 1.100 \\
\hline Soledade & 1.850 & 1.793 & 2.756 & 2.704 \\
\hline Tupaciretẫ & 851 & 832 & 1.501 & 1.364 \\
\hline Zona do Noroeste & 3.932 & 3.803 & 13.596 & 12.750 \\
\hline Jjui & 652 & 684 & 750 & 718 \\
\hline Iraí & 477 & 461 & 906 & 861 \\
\hline Palmeira das Missbes & 1.086 & 1,035 & 2,017 & 1.932 \\
\hline Santa Rosa & 624 & 575 & 3.117 & 2.932 \\
\hline Sarandi & 612 & 606 & 1.474 & 1.358 \\
\hline Três Passos: & 481 & 442 & 5.332 & 4.949 \\
\hline Zona da Campanha & 14.348 & 14.524 & 14.793 & 15.216 \\
\hline Alegrete & 1573 & 1.686 & 2.859 & 2.849 \\
\hline Bagé & 3.493 & 3.500 & 2.420 & 2.482 \\
\hline Cacequi & 545 & $\$ 01$ & 917 & 945 \\
\hline Dom Pedrito & 1.681 & 1.655 & 653 & 689 \\
\hline Livramento & 1.975 & 2.089 & 1.332 & 1.464 \\
\hline Quaraí & 350 & 363 & 813 & 828 \\
\hline Rosário do Sul & 1.421 & 1.400 & 773 & 817 \\
\hline Sẵ Gabriel & 1.988 & 2.013 & 1.029 & 1.210 \\
\hline Unguaiana & 1.322 & 1317 & 3.997 & 3,932 \\
\hline Zona das Missธ̄es & 5.273 & 5.251 & 9.633 & 9.457 \\
\hline Itaqui & 366 & 278 & 1.197 & 1.125 \\
\hline Jaguari & 195 & 215 & 849 & 834 \\
\hline Santiago & 820 & 879 & 828 & 826 \\
\hline Santo Ảgelo & 1.082 & 1.111 & 2.349 & 2.200 \\
\hline Sáo Borja & 627 & 665 & 2.142 & 2.093 \\
\hline Sán Francisco de Assis. & 574 & 530 & 993 & 1.037 \\
\hline Sấo Luís Gonizaga & 1.606 & 1573 & 1.275 & 1.342 \\
\hline
\end{tabular}




\section{SEGUNDA PARTE - ASPECTO HISTÓRICO}

\section{I-Mercados}

Os negros concentravam-se no litoral, desde Săo Paulo até a foz do Amazonas.

A entrada de escravos feita pelos portos principais, ao norte, de Recife e São Lais, ao centro, da Bahia, c âo sul, Rio de Janeiro e São Vicente, nĭo os afastou muito da costa.

Os primitives focos da entrada de escravos se ramificavam por São Paulo, Rio de Janeiro e Minas, formando o primeiro grupo de distribuiçáo; a Bahia, por si so, constituia um segundo grupo; Alagoas e Pernambuco, compunham o grupo do nordeste e Maranhăo e Pará o grupo do extremo norte de distribuiçāo de escravos.

Os focos de entradas de eseravos partiam dos portos, ampliando-se nas zonas das provincias mais importantes.

Os negros que vieram para o Brasil faziam parte dos tres agrupamentos étnicos africanos: sudaneses, bantus e bantuides.

\section{II-Cultura}

O ramo ou naçăo do culto africano é um problema de grande importância, verificando-sc, antes de mais nada, que se filia o culto negro à naçẫo ou ramo do contimente de origem, entretanto, nảo se pode dizer

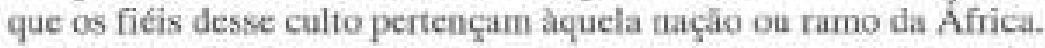

As populações negras nầo conseguiram manter-se absolutamente separadas no Brasil, isto $\dot{\epsilon}$, povo por povo, naçào e ramo por ramo.

Foi fatal o contato e a mistura, tornando-se impossivel estabelecer o limite ou área em que viveu cada povo da África no nosso país.

Atualmente, no Rio Grande do Sul, o culto africano procede de três naçôes;

$$
\begin{aligned}
& \text { - Nagó } \\
& \text { - Gege } \\
& \text { - Oió. }
\end{aligned}
$$

Existem 29 casas nagôs, 28 geges e 15 oiós, em Porto Alegre, segundo as respostas ao inquérito que pessoalmente projetamos e realizamos. 
Das seis casas que estudamos, 4 sīo geges, 1 gege ou nagô e 1 nagô, nẵo se registrando oió, no caso particular do culto de $\mathrm{N}^{2} \mathrm{~S}^{2}$ dos Navegantes, que em separaçio apreciamos de uma feita.

Săo as geges: Soc. Africana N' $S^{7}$ dos Navegantes (rua Baronesa de Gravatai), Soc. Africana N $\mathrm{S}^{\mathrm{a}}$ dos Navegantes (rua Otávio de Souza) e Casa 15 de Março (rua do Livramento).

Ế gege ou nagô: Soc. Beneficente Africana $\mathrm{N}^{3} \mathrm{~S}^{t}$ dos Navegantes (rua Barbedo). Quer dizer que a casa é mesmo gege-nagô. Gomes).

É nagồ: Associaçäo Africana $\mathrm{N}^{*} \mathrm{~S}^{*}$ dos Navegantes (rua Rodolfo

Quanto ao exame total das casas visitadas para o inquérito:

Das 29 do ramo nagô, 16 apresentaram uma frequiéncin mêdia superior a $50,9 \mathrm{com}$ frequência média inferior a 50 e 4 com frequểncia média de 10 pessoas, 26 casas de madeirase de alvenaria. Contando com um total de 148 Filhos de Santos prontos do sexo masculino e 158 do sexo feminino.

Das 28 do ramo gege, 14 casas apresentaram um frequência média superior a 50 e 14 com frequuetncia média inferior a 50,24 casas de madeira, 14 de alvenaria.

Contando um total de 62 Filhos de Santo prontos do sexomasculino e 64 do sexo feminino.

De 15 do ramo oio, 8 casas apresentaram uma frequência superior a 50 e 7 com uma frequêtucia média inferior a 50 pessoas, 14 casas sâo de madeira e 1 de alvenaria. Contam um total de 84 casas sã́o de madeirat. Contam um total de 84 Filhos de Santo, prontos, do sexo masculino e 168 do sexo ferninino.

Limitamo-nos a seguir à risca o que se obteve do informante $\mathrm{cm}$ assunto de naçào africana.

Registramos os geges, os nagós e os oiós, e, conforme a liçĩo de Arthur Ramos, na sua "Introduçăo à Antropologia Brasileira", $1^{*}$ vol. As culturas nāo-curopéias, sâo trếs africunas, naçōes ou grupos que estâo incluídos nas áreas de culturas sudanesas.

Explica o mestre, que "na tentativa de reconstruir as culturas negro-africanas, abandonamos qualquer ponto de partida, com relaçăo a dados históticus, a números, absolutos e relativos, e as listas de nomes tribais, repetidas pelos nossos historiadores. Guiado pelo método preconizado pelo professor Nina Rodrigues, e utilizando-me das suas pesquisas iniciais da Batia e as que estâo scndo continuadas hoje por toda uma série de investigadores, e com os resultados das minhas próprias obser- 
vaçōes e pesquisas (Bahia, 1926-1933; Nordeste, 1930-1933; Rio de Janeiro, 1933), apresenta o seguinte quadro dos padrö́es de culturas negras sobreviventes no Brasil",

Seguimos o mesmo método, desprezando as informaçōes unteriores, aliás modesta, sem valor científico algum e até mesmo medioctes.

O levantamento estatístico é de fato coisa à parte porque năo nọ referimos an nùmero de negros mas à procedência deles.

Bem sabemos que negros de todas as áreas da África vieram ter com raras exceçóes, ato Rio Grande, mercado de negros soldado5, operários da indústria do charque ou agricuitores, colonos ou brancos principalmente no plantio do trigo.

Mas as culturas respectivas sobreviveram ou uma dessas culturas sobrepujou as outras.

A. Ramos classifica em trếs padrōes, como se disse, as culturas negras que resistiram no Brasil.

"A) Culturas Sudanesas - representadas principalmente pelos povos yoruba, da Nigéria (Nagó, Ijechá, Eubá, Ketu, Ibadan, Yebu ou ljebu e grupos menores), pelos Daomeianos (grupo Gege; Ewe, Fon ou Efan, c grupos menores); pelos Fanti-Ashianti, da Costa do Ouro (grupo Mina propriamente dito; Fanti e Ashanti); pró-grupos menores da Câmbia, da Serra Leoa, da Liberria, da Costa da Malagueta, da Costa do Marfim... (Krumano, Agni, Zemu, Timini...).

"B) Culturas gumeano-sudanesas islamizadas, representadas $\mathrm{cm}$ primeiro lugar pelos a) Peuhl (Fulah, etc. b) Mandinga (Solinke, Bambara...) e c) Haussá do norte da Nigéria; e por grupos menores com os Tapa, Bornu, Ourunsi, e outros.

"C) Culturas bantus, constituidas pelas inúmeras tribos do grupo Angola-Congoles e do grupo da Contri-Costa".

Voltando a A. Ramos, noutra passagem de seu livro de antropologia brasileira, ao falar das culturas sudanesas e sobre quais as tribos Youruba que vieram ao Brasil, diz que "Nina Rodrigues ainda conseguiu na Bahia, em fins do século passado, ver negros Nagôs de quase todas as pequenas naçōes Yorıba. Eram ainda, na sua épocn, os mais numerosos e influentes naquele Estado. Os mais freqüentes eram oyó (oí), provenientes da cidade do mesmo nome do reinado de Alafin".

Temos, entaío, que os

- Gege

- Nagó

- Oíó 
pertencem aos mesmos grupos culturais sudaneses com as subdivisöes seguintes:

a) Cultura Daomeiana e o grupo gege no Brasil

b) Cultura yoruba e o grupo nagó no Brașil, incluindo-se os oíó,

Esclarece, ainda, o professot que estamos citando as "culturas" que nầ se mantiveram puras no novo ambiente.

"Misturando-se umas com as outras", nāo só as culturas africanas, entre si, mas "com as culturas de procedencia amerindia e européias que encontraram no Brasil".

Mas o que precisa ficar assinalado é que as culturas sudanesas se impuseram sobre as demais, ao ponto delas desaparecerem do Rio Grande do Sul, pelo menos em Porto Alegre que todas as 71 casas de culto afrieano existentes acusaram, no sistemn, o avassalador domínio sudanês através das culturas daomeanas e nagôs com oió que lhe pertence.

A antropologia física, a filologia e a história das populaçōes afrobrasileiras do Rio Grande do Sul assinalam também diferentes arigens mas, entretanto, uma se sobrepôs, que foi a sudanesa, isto é evidente, no campo religioso.

Näo resistiram, entre nós, es negros e seus descendentes, oriundos de estoques tribais diferentes, à força espiritual da mitologia sudanesa.

C. G. Seligman, professor de etnologia da Universidade de Londres, em seu livio "Les Races de l'Afrique", ediçăo francesa inaduzida por George Montandon, professor, também, de etnologia, da Escola de Antropologia de Paris, adverte que a África Ocidental t a pátria do verdadeiro negro:

"L'Afrique occidentale, la parric du vrai Nègre, peut être considérée comme s'étendant de la bouche du Sénégal au $16^{\circ}$ Nord environ, jusqu' à la frontiere orientale de la Nigéria. Si l'Afrique occidentale est ainsi défine, sa limite orientale coincide avec la limite la plus septentrioaale du domaine bantou, le long du cours inférieur da Rio del Rey. Politiquement aucune partie de l'Afrique ne présente plus de confusicn, puisqu'elle consiste en une série d'enclaves s'étendant de la côte vers l'atriere-pays; chacune de ces enclaves a pris origine dans un centre commercial de la côte, établi entre les XV e et XVIII siècles, et elles appartiennentalternativemente à la France et à la Grande-Bretagne, avec, pour ajouter à la confusion, une possession restante du Portugal et le république negre, constituéc par des esclaves libérés, de Liberia. II es aécessaire d'insister sur ces faits pour expliquer des termes telsque "Còte 
des Esclaves". "Côte d'Or" et rendre comprehensible la division arbitraire du pays sans qu'il été tenu compte des liens locaux ou des associations tribales, Ces enclaves sont, du Nord au Sud puis vers l'Est: le Sénégal (Fr.), la Gambie (Angl, le Liberia, la Cote d'Ivoire, (Fr.), la Cote d'Or (Angl.), le Dahomey (Fr.), et la Nigeria (Angl.), toutes s'allongeant vers l'intérieur et baiegnant dans cette grande masse africaine appelée connmunément le Soudan Français".

Os estudos das naçoes, "ramos" ou paises africanos tèm, entre seus especialistas, a D. P, de Pedrals, antigo administrador de colònias, que escreveu um "Manuel Scientifique de L'Afrique Noire" sobre antropologia, pré-história, arqueologia, culturas e artes, instituiçốes sociais e políticas e história.

"Les royaumes dont les chroniques des navigateurs européens ont laissé le souvenir, et qui ont parfois plus ou moins survécu, sont en fait sur les rives mêmes de l'Océan de petits royaumes isolés, dispersés de peu d'étendue, souvent séparés par des territoires oú létat régnant est celui de l'anarchie. En rétrait par contre, l'invasion de peuples de souche soudanaise, aboutit encore ì la fondation de deux puissants empires; celui des Ashanti, et celui des Yoruba, entre lesquels s'illustra un royaume qui fit beaucoup parler de lui: le Duhomey. Dans un sens, T'histoire des Ashanti et des yorouba, aurait pue être considéreé en même temps que celle du Mosi et du Borgou. Le contact avec les aborigénes des cótes imprime toutefois à son déroulement des caractêres un peu différents".

"La confedération yoruba, mềme à son apogé, n' ávait pas compris dans son étendue, un royaume pourtant de même origine, que s'etait constitué au sud à quelque distance de la cóte, au XIII siécle le Bénin (de Bini, nom de la Fraction yorouba venue du Soudan et qqui s'imposa aux aborigénes Efa). Le premier roi ou obba, fut Igoudou qui vers le XIIe ciécle s'établit à Oudo. Vers 1300 , le roi (aouni) d'Ifé envoie son fils Orhamiyan, acompagné d'une nombreuse suite à Ousé. Les nouveaux venus s'imposent. A Orhamiynn, succéde Ewoké, puis Omovberhé ou Erhanome et Ogouola, qui en 1370 aggrandit considérablement le royaume. Au début du XIVe siécle, se déroule une période d'anarchic, puis le pouvoir est rétabli et le royaume de Bénin, au moment oú les Portugais abordent en ces régions (1485), offre le spectacle d'une parfaite organisation et de la remarcabble culture dont les produits sont parmi lesplus réputés de l'Afrique nord tout entiére". 


\section{III - Trabalho}

Iniciando o trabalho agrícola, os açorianos não poderiam contar somente consigo mesmo, e apelaram para os negros.

Numa zona de plantio de trigo, em Piratini, un recenseamento de 1814 dá os seguintes índices: brancos 1.439 , índios 182, livres (de côr) 335 , nascidos em 1814, 182, escravos 535. Total 3.673.

Contudo, bastou que passassem dez anos, quando se substituiu o açoriano pelo alemão, para atenuar a entrada de negros nas propriedades agrícolas.

Leonardo Truda, na sua Colonização Alemã no Rio Grande do Sul comenta que o estrangeiro, o colono alemão, tinha verdadeira repulsa ao negro.

O município de Santa Cruz, em 1887, não possuía um escravo, sequer.

"Mas o colono não dispunha, ao tempo, de recursos para tornar-se senhor de escravos. E, uma vez encaminhadas as tarefas de cada "colônia", iniciadas as plantações, o negro representaria apenas uma boca a mais a consumir, e a pesar, portanto, no orçamento doméstico, sem compensação na soma do trabalho produzido e da qual a própria família do colono poderia incumbir-se".

Houve necessidade, do negro no início da colonização agrícola, porque a derrubada das matas e as estradas eram habilmente feitas pelos escravos africanos.

A nossa própria vida econômica define o estado e as condições para o trabalho.

Como observa Jorge Salis Goulart, na sua "Formação histórica do Rio Grande do Sul"; "O trabalho pastoril sempre exigiu menos braços do que a agricultura, de modo que a própria família do estrangeiro podia atender à maior parte das necessidades de seus rebanhos. Enquanto em outras capitanias a indolência indígena reclamava a importação de escravos da África, aqui o índio se adaptou à principal indústria da terra e se tornou um elemento de valor".

A pastagem, o banho, rodeio duma tropa de gado, em mil cabeças por exemplo, não exigirá senão uns dez homens, mais ou menos.

Foi somente quando a pecuária evoluiu para uma indústria em determinadas zonas mais adiantadas da Província ou do Estado, ao mesmo tempo do início do trabalho agrícola, que se tornou necesssária a colaboração de elemento estranho. 
As charqueadas de Pelotas e Porto Alegre e as plantaçóes de trigo de Bagé e Piratini tinham precisáo de braços para o trabalho bruto.

Nas charqueadas, os transportes de mangas, a matança, a pesagem e os mais fortes serviços da indústrin saladeril bem como o plantio e u colheita de vastas regióes de trigais nẫo podiam ser atendidos pelı escassa populaçăo ocupada teda cla noutros misteres.

Ai, entăo, se apelou para o negro, que sustentara e sustentava a economia brisileita.

Era o escravo, além de sua enorme resistência física, um bom emprego de capital.

A razâo pela qual o colono alemáo déixou de interessar-se pela escravidĩo negra é bem outra. Uma determinaçấo oficial a proibia, como se vê na Lei $n^{\circ} 183$ de 18 de outubro de 1850 , que estít redigida nos seguintes termos:

"O Conselheiro José Antonio Pimenta Bueno, Presidente da Provincia de Săo Pedro do Rio Grande do Sul e Santa Catarina:

Faço saber a todos os seus babitantes que a Assembléia Legislativa Provincial decretou, eu sancionei a Lei seguinte:

Art. $1^{\mathbb{E}}$ E proibida a introduçáa de escravos no territónio marcado para as colônias existentes, e para as que para o futuro se formarem na Provincia.

Art. $2^{\circ}$ Os escravos, que atualmente existem no territorio das colônias, serão matriculados pelo diretor, ou seus agentes, em livro próprio dentro de dois meses, depois da publicaçăo desta Lei, fazendo-se no mesmo livro nota dos que falecerem.

Art. $3^{3}$ Todas as pessoas, que forem viajar às colônias, ou residirem! nelas temporariamente, poderáo levar os escravos precisos para seu serviço doméstico, sendo obrigados a enviar ao diretor ou seus agentes, uma relaçáo dos mesmos escravos e a a reconduzi-los para fora das colônias, quando se retirarem.

Art. $4^{\circ}$ Os escravos que forem introduzidos nas colônias, em contravençĩo a esta Lei, serỉo expelidos por ordem do diretor, pagas as despesas pelos donos dos mesmos escravos.

Art. $5^{\prime \prime}$ As disposiçũes acima referidas compreendem igualmente as colōnias formadas por particulares.

Art. $6^{\circ}$ Por cada escravo importado na Provincia se cobrará, para auxílio da colonizaça, a taxa de trinta e dois mil réis.

Art. $7^{4}$ Não serāo sujeitos à taxa:

Parágrafo $1^{2}$ Os escravos inscritos na matrícula dos navios. 
Parágrafo $2^{2} \mathrm{Os}$ escravos do serviço doméstico das pessoas que vierem residir temporariamente na Provincia.

Parágrafo $3^{\circ}$ Os escravos existentes na Província, que saindo dela com seus senhores voltarem com os mesmos, ou forem reenviados pelos mesmos senhores dentro de um ano.

Art. $8^{2}$ Ficam sujeitos à taxa os escravos de que tratam os parágrafos $1^{10} \mathrm{e} 2^{2}$ do artigo antecedente, que não sairem da Província com os navios, e senhores que os trouxerem.

Art. $9^{\circ}$ Ficam revogadas as disposiçóes em contrário.

Mando portanto as autoridades a quem o conhecimento a execaçấo da referida lei pertencer, que a cumpram e façam cumprir tho inteirameate como nela se contém. O secretírio desta Provincia a faça imprimir publicat e corret.

Palácio do Governo na Leal e Valorosa Cidade de Porto Alegre aos 18 de outubro de 1850 , vigésimo nono da Independéncia e do Impétio. José Antônio Pimenta Bueno (I.S.).

Carta de Lei pela qual V. Ex. sancionou o Decreto da Assembléia Legislativa Provincial, proibindo a introduçāo de escravos no território marcado para as Colónias, e impondo a taxa de trinta e dois mil réis, por cada um dos que forem importados na Provincia; e dando outras providèncias como acima se declara.

\section{Para V. Ex. ver}

Germano Severino da Silva a fez.

Nesta Secretaria do Governo foi selada e publicada a presente em 18 de outubro de 1850.

José Mauricio Fernandes Pereira de Barros

Registrada a fls. 77 do Livro $2^{\circ}$ de Leis. Secretaria do Governo em Porto Alegre, 18 de outubro de 1850.

Rodrigo José de Figuciredo Moreira Jünior

\section{IV - Exército}

\section{Tropas coloniais}

"Respondeu que vindo com licença do Sargento-Mor Manuel dos Santos Pedroso por espaço de dez dias para vir ao Quaraim em busca de 
um escravo seu...", depunha uma testemunha referida, Manuel Gomes Lisboa, cabo d'Esquadra de Milícias de Partida, morador da Freguesia de Cachoeira, num processo instaurado, em 1812, num crime de rovbo da tomada de cavalos feita aos Charruas e Mimuanos.

O escravo merecia muita estima ou era um elemento precioso para esse cabo de esquadra que arrisca sua própria liberdado, atravessando vastas regiōes, afim de recuperar um escravo.

"No dia 3 apresentou-se neste acampamento, preto que tendo sido escravo do cap. Antônio Adolfo Chartio e fugindo hà sete anos para os dominics de Espanha, onde ocupava o lugar de artilheiro nas tropas dos Insurgentes. Desertando, procurou o seu primeiro senhor, que sc acha preso em uma das Guardas da Coluna..." informa uma parte datada de 5 de dezembro de 1812, no acampamento da Conceiçio assinada pelo comandante Joaquim Xavier Curado ao Governador D. Diogo.

Avalia-se que um escravo regresse depois de sete anos de foragido pan encontrar-se o seu antigo senhor entāo prisioneiro, porque se um homem branco procure reaver seu escravo năo é de estranhar mais que preto escravo deseje revet seu senhor; ai se define um caríter.

Um simples depoimento pôe à mostra uma organizaçílo de uma raça cuja dedicaçấo poucas a igualam.

Quando um graduado da guarda do Cerrito, Silvestre Teixcira Pinto, procurava, em 1800, defender-se junto aso governador de ter prendjo um escravo depois de o vender: "... pelo qual requeria a indenizaçato de um escravo, que eu the havia vendido, a ele me havia pago, figurando-o a V. Excia, outra vez em meu poder..."

Naturalmente nâo se pode concluir nada sobre o negro mas o oficial reinol que desejava, ao que parece, fazer renda. ordem.

De qualquer maneim, o negto era uma fonte de interesse de toda a

Na guarda do Cerrito ou na freguesia de Viamāo, o negro exercia um importante papel.

"Dentre as fronteiras terrestres do Brasil os limites com Uruguai constituem a "fronteira viva", isto é, aquela por onde transitum as mais intensas relaçóes que irradiam do interior do nosso país, por via continental. Corno, por via outro lado, provinientes do Uruguai, poderosas e constantes correntes de toda a ordem atingem o solo brasileiro", observat Afonso Várzea, no seu livro "Limites Meridionais do Brusil". 
É ainda a sobrevivência dos entrechoques đo século XVIII o de hispano-rio-platenses e luso-brasileiros, avanços c recuos nos dominios des dois monarcas.

Substituiram-se boje as forças armadas pelas forças cconômieas mas a "fronteira viva" 6 uma realidade desde os marcos incertos das dinastias senhoras da América do Sul.

"... que para se servirem algumas forças nesta Fronteira é muito necessário novo perdāo para os desertores, que a rigor pouco se pode arrumat, pela extensio desta Campanha, talvez que muitos se unam aos Portenhos..." oficiava José Francisco Muniz às autoridades e eram comuns mensagens desse teor, o que năo obstava que ao mesmo tempo o governador D. Diogo dissesse ao Vice-Rei, conde de Linhares, que "... fazesdo-se bem notável, que não só tem cessado muito as deserçóes desde que constou havia intençăo de passar aos territórics espanhóis más se tem recolhido aos seu corpos quase todos os duzentos deles nesta Capitantia..."

As ordens gerais da campanha, em $1816-19$ na coluna do tenentegeneral Joaquim Xavier Curado, constam repetidas vezes de disposiçóes. e penas sobre fugas, cabendo ao negro os castigos maiores,

"... e que sejam Castigados com 50 pancadis de espada de prancha, aqueles que forem encontrados fora de seu corpo" e "... quando algum soldado alterasse razōes com o seu camarada, seria castigado, com 30 bordoadas",

"Os escravos ou criados levaram um bilhete de seus amos, ou senhores que ficaram responsíveis pela sua conduta... "quando se físcalizava aos pedágios, trânsitos em zonas de operaçăo, recebendo os infratores: "... Escravos e criados com 50 pancadas de vara ou pau que vergue, e os soldados carregados com 8 armas, por espaço de 2 horas, e dada uma hora de descanso se repetirá o mesmo castigo..."

Procurava-se estabelecer uma flagrante diferença mesmo nas penas corporais.

Os negros eram atingidos por pesados castigos.

"... e que o mesmo capitao tem ordem para mandar prender os soldades, indios, criados, e escravos que passarem ao outro lado do bosque por qualquer motivo que seja, e que mandarí castigar pronta e imedialamente na guarda da frente da legião de São Paulo, os soldados e criados brancos com 50 pancadns de espada de prancha, os indios, e os escravos com 200 açoites, sendo amarrados na culatra de uma peça" ou "... os pretos, mulatos ou naturais que forem alistados em qualquer dos 
corpos milicianos, e se encontrarem montados $\mathrm{em}$ cavalos reiúnos serảo castigados com 50 pancadas de pau que vergue e presos por espaço de 8 dias, empregados na limpeza dos seus respectivos corpos".

Enquanto os mesmo altos comandantes se dirigirio fos govermadores em linguagem duma bajulaçăo revoltante muito ao sabor dos taparês da época:

"... e pela moderada reprecnsão q. V. Ex. me dí the beijo as mīos" ou Respeitosamente beija as ilmas, e exmas. mãos de V. Ex. o súdito mais obedienie" ou "sudito humilde vassale",

Parece tambem que os oficiais naso se tratavam muito delicadamente entre si como se lê no termo do inquérito da Calcria, $\mathrm{cm} 1812$, "que o capitâo Sebastiầo Barreto Pereira Pinto, do Regimento de Dragồes, havia dado com um pau no furricl Joaquim Manoel Ribeiro do mesmo regimento".

Mesmo assim o preto era tratado desprezivelmente, nas ordens oficiais, como assim: - '... Todos pretos, mulatos, ou naturais, que nĩo tiverem a honra de ser alistados em qualquer dos corpos milicianos.."

\section{Tropas farroupilhas}

Os negros constituiram, por todos as títulos, um elemento importante nit revolução farroupilha.

Rompera o movimento de 1835 , quando, perante a justiça de Paz. do $2^{\circ}$ distrito de Porto Alegre, em 14 de outubro de 1836 , instaurou-se o competente processo sumário por crimes de rebcliāo, sediçâo, peculato, cumplicidade de homicídio, ferimentos, roubos e outros crimes graves contra os lideres da Revoluçấ.

Perante o juiz de paz, capitāo Mancel José da Cămara, depuseram, entāo muítas testemunhas, que forneceram, assim, subsidios ao estudo dos acontecimentos.

Justamente os primórdios, o início das hostilidades guerreiras contra o lmpério, é que poderiam definir uma atitude.

Mas os negros entraram desde os primeiros dias com o seu quinhấ.

O depoimento mais original é do advogado Agostinho José de Menezes que disse:

" e de diversas insurreiçōes de escravatura que eles, cabeças e agentes fizeram armar e reunir em diversas pontos da Província como fossem na ocasiảo em que os rebeldes acometeram esta cidade e na 
cidade de Pelotas aoade ainda conserva para mais de trezentos a qualrocentos escravos, armados contra a causa da legalidade.,."

Outro depoimento, como do cap. Inácio da Silva, Joaquim Barrot, Manoel Ferreira, Pereira Dias, Cel. Paula Soares e Lobo Barreto, nos dão o número de escravos que viram nos movimentos de forças dos farrapos.

No avanço sobre a capital, em 20 de junho e em 30 de julho, e no cerro de Pelotas, em 1836, maream os passos iniciais e importantes das guertas de dez anos, os escravos negros tiveram um lugar de primeiro plano.

Os negros, escravos ou libertos, iam, daí por diante, tomar as posiçōes salientes.

Foram eles elementos de colaboraçūo, eutraram com os primeiros insurretos, estiveram ao par dos segredos revolucionários e tomaram parte nas horas iniciais.

OMajor Joăo Manoel Limn comandou a primeira legiấa de escravos que entrou em Pelotas.

Mais tarde os negros se distribuiram per todos os setores de armas da República.

Os negros dos pastoreios sāo incluídos aa cavalaria e os negros das zonas agrícolas stio para a infantaria.

".. um Antônio Joaquim da Silva, por alcunha 'Menino Diabo' porque este não só andava bostilizando como comandante de lanchōes guamecidos e armados", depunha o funcionário da tesouraria geral, Pedro Azevedo e Souza, no Juizo de Paz.

Uma vez, estando Garibaldi com seus marinheiros em terra, em Camaquă, Pedro Moringue thes surpreende os passos, usando a astúcia e surpresa; mesmo assim as forças imperiais encontraram uma resistência respeitavel.

Entre estes companheiros do herói italiano, estava Nascimento Rafael e Procópio, que eram dois negros.

"Quisera um lugar para escrever no papel, gravar no bronze os nomes destes valentes companheiros, que no numero de treze se me reuniram, combaiendo durante cinco horas cinquienta inimigos" narra, em suas "memórias", o gềnio de Caprera.

Na absoluta falta de dados, como alíśs em quase tudo que precisamos para estudar, sobre o negro na guerra republicana de 35 , mío temos senẩo a tradiçẫo de um heró́smo, que nem sempre se tem reconhecido.

O sentimento abolicionista foi da indole do rio grandense. 
Quase todos os maiores proprietários que faziam uso do traballo do preto, libertuvam seus próprios escravos.

Mas umin figura nos surge, trinta anos antes dos farrapos, clamando contra o crime da desigualdade da cot,

Era Alexandre Luís, tipo romântico, que fol para Aurélio Porto colocado numa novela hístónca.

Alcxandre Luís, como Borges do Canto, conquistaram, ainda com um punhado de desertores, as Missỏes para a coroa portuguesa. aboliçílo:

Esse "doido" trés vezes fez ecoar no Rio Grande do Sul o grito da

1803 domina a guarda de São Pedro com uma legiăo de escravos. Proclama a Repáblica e emancipa os servos.

1820 o cenfirio agora é Cachoeira, que começava a florir. Chama a si os escravos da vila e toma a cadeia, soltando os presos, manda degolar os portugueses e proclama, pela República Rio-Grandense, a igualdade dos homens.

1831 chegava o herói in Caçapasa, levando o mesmo grito de libertaçầo dos escravos. Longe, noutro canto da Provincia, e os alemấes, que traziam dentro de si a pureza duma civilizaçào livre, ouvem o eco daquele que pela terceira vez levantava sua voz pelos oprimidos. Desta vez nâo ficara sozinho o dominador đas Missōes. Mais alguém a compreendia.

Alexandre Luis, ora preso, ora fugindo das forças governistas, morre cm 1833, mas define o ambiente cm que viveu.

Os republicanos davam aos negros escravos o próprio direito de cidadania, bastando que eles aderissem à causa e formassem fileiras nos seus exércitos.

A façaio contrária procurou atruir os escravos, oferecendo-lhes us mesmas regalias de libertięĩo aos negros.

Quatro anos depois, em 1839, começava o Império a por em voga, também, a libertaçä̀o dos negros,

Masum alto dignitário do Imperioers o primeiro a escrever à Corte:

"Os rebeldes nîo dáo mau tratameato in fodos os negros".

O5 farrapos tinham envolvido os escravos nas suas simpatias.

O governo de Piratini cansava seus francos na compra de escravos, pois seus senhores assim o exigiam, na maioria das vezes.

Uma vez libertados os negros, as autoridades da República thes asseguravam a mesma garantia que tinha qualquer cidadão do país, que recentemente se formavi. 
Assimé que Bento Gonçalves, com Domingos de Almeida, Ministro da Justiça e Interior, ussinnvam, em 11 de maio de 1839 , um docreto, que, depais de algumas consideraçôes, terminava assim:

"... O Presidente da República para reivindicar os direitos inalientiveis da humanidade, năo consentindo que o livre tiograndense de qualquer cor com que os acidentes da natureza os tenham distinguido, sofra impune e náo vingando o indigno, bárbaro, e afrontoso tratamento, que the prepara o infame govemo imperial, em represália, a que lhe tem provocado, decreta:

Artigo Unico: Desde o momento em que houver sido açoitado um homem de cor a soldo da República pelas autoridades do Governo do Brasil, o General Comandanto em chefe do Exército, on Comandante das diversas divisóes do mesmo, tirará a sorte aos oficiais de qualquer grau que sejam das tropas imperiais nossos prisioneiros e faria passar pela armas aquele que a mesma sorte designar".

Ainda, no mesmo més, a Republica, pelo seu presidente, tratava dos escravos negros com sentimento de abolição do trabalho servil, que sempre a caracterizou nesses rumos democráticos e avançados, o decreto dizia respeito à fuga de escravos das forças farroupilhas.

Mas o espírito liberal que dominava a cultura de 35 , fazia, nesse decreto, uma ressalva que dava ao negro seu lugar na ordem comum dos homens.

Eis a ressalva: "... que manda volver o forro ao domínio do senhor que o libertará sempre que este o possa convencer de ingratidāo, depois de ter-lhe dispensado tâo inapteciível beneficion".

Quando a República rio-grandense obteve paz com o Império, os farrapos impuseram, no tratado de paz, uma clíusula, a quarta, que dizia:

"Sáo livres e como tais reconhecidos os cutivos que servirum na Revoluçāo".

Os republicanos nẫo esqueceram seus colaboradores, os escravos negros rio-grandenses.

\section{V-Viajantes}

-Saint-Hilaire (1820-1821)

- Nicolau Dreyes (1817-1837)

- Arsène Isabelle (1833-1834) 
A viagem de Saint-Hilaire, pelo Rio Grande do Sal, teve duas fases. O intervalo delas foi marcado pela estada no Uruguai. Em 5 de junho de 1820 tinha passado o rio Mampitube, deixando Santa Catarina para entrar na nossa província. E em 9 de outubro atingia Angustura, passando ì Cisplatina para voltar, pelas margens do rio Uruguai, chegar a Sāo Borja e daí até no Rio Grande, durnando seis meses todo o segundo percurso.

Teve, assim, a excursuio um periodo de cinco $\mathrm{c}$ outro de seis meses. Portanto quase um ano, o cientista francés permaneceu em estudo no pampa brasileiro.

Atravessou o Rio Grande em duas enomes diagonais. Do extremo nordeste da costa marítima ao território fronteiro no Prata oriental e das Missōes argentinas até o sul nn costa, para atingir a nossa porta marítima.

Estava sendo mudado o cenário histórico. Plena transição politica.

D. Joĥo VI tirara, entāo, o maior proveito das lutas internas do Uruguai.

Nasceram, com a nova magna carta, as juntas governativas e o Conde da Figueira deixa o Rio Grande, substituindo o um governo interino, $\mathrm{cm} 22$ de setembro de 1820.

Houve um motim militar em Porto Alegre e o povo que promovera a agitação exige o compromisso do governo respeitar a constituição.

A volta do rei para Lisboa velo acelerar o entusiasmo de emancipação dos brasileiros. A regência do príncipe D. Pedro tinha dado o direito de elegerem-se deputados às cortes de Portugal e mudava as capitanias $\mathrm{cm}$ provincias.

Estávamos na luta aberta pela independềncia.

O testemunho de Saint-Hilaire, por mais cssa razäo, é precioso.

Todos os viajantes, ingleses ou alemães, franceses ou portugueses, que escreveram sobre o Rio Grande nilo atingiram à expressăo de verdade como o naturalista da cidade de Joanna D'Are.

Rápidas impressôes, comentários de geologia, anotaçôes etnogrificas e linguísticas ou relatórios geográficos c mineralógicos crum que constituiam as nurrativas publicadas em livros.

Orbigny, Borpland, Lisle, Luckok, Seidler, Feldner, Dreys, Selow e alguns outros autores de pesquisas sal-riograndenses, apesar do esforço e do mérito de seus estudos, năo possuem o humano, que em Saini-Hilaire é ums atitude natural.

Entretanto a divinlgaçầo da obra do mestre francếs deve-se a Editoera Nacional, que fez a publicaçio integral do grande documentário brasileiro. 
Adroaldo Mesquita da Costa traduzira, em elegante português, alguns capítulos da "Voyage à Rio Grande do Sul" que apareceram na revista do nosso Instituto Histórico e Geográfico.

Também Renato Costa, autor dum magnílico "Ensaios de História", tinha passado, para a língua de Carnilo, a viagem do ilustre francés. Félix Contreiras Rodrigues parece que é autor duma outra traduçăo.

Afinal apareceu impressa, em ediçaío Aricl, essa "Viagem ao Rio Grande do Sul".

É uma traduçio de Leonam de Azevedo Pena, Bem feita e cuidadosa.

Recolhemos da viagem ao Rio Grande do Sul dezoito espécies de notas em einquientu observaçōes sobre o negro.

"Nas primeiras páginas do livro, Saint-Hilaire faz referências aos seus companheiros de excursăo: um mestiço, um negro forro $\mathrm{e}$ um indio botocudo.

- Torno-me pouco a pouco escravo de José Mariano: Manoel só me fala com ar insolente e Firmino, sendo o melhor, é todavia de tamanha susceptibilidade que exige ser tratado com as mais fatigantes precaucŏcs.

Manoel, que é o negro forto, viera de São Paulo e José Martimo é um tropeiro mestiço alugado no Rio de Janeiro. Queixa-se amargamente o muturalista que se torna pouco a pouco escravo de um preto,

As condiçoses de vida no Brasil tinham chegado a um ponto que nem o ricaço dos cafezais ou o abastado plantador de cana de açúcar podiam dispensar o negro. O homem africano era um meio de transporte: cartegador, tocador de animais, cangueiro...

A vida doméstica se regiat pelos negros da familia e desde a àgua para o banho até a cozinha, foram misteres cuidados pelo homem de cor. Os casarōes das cidıdes tornavam-se habitáiveis porque os pretos desciam e subiam enormes escadarias, carregando sobre a cabeça o que era necessário para manter o modesto ritmo econômico do luso-brasileiro. O senhor da charqueada ou comerciante do sobrado sem luz direta, também, nảo passavam de escravos do negro. Ai então que o africano mostrou saa grande força física e moral. Tornou-se insubstituível.

Mas năo escapou ao sábio francês, e quantas vezes insistce, a superioridade do negro. Ao menos a superioridade do negro sobre o indio. Os negros, raça tăo distante da nossa também, săo entretanto superiores aos indios. Seu juizo não e táo bem formado quanto o nosso.

Eles conservam qualquer coisa de infintil em seus modos, linguagem e idé̉as mas não sầo estranhos a concepçẫo do futuro. Tem-se visto 
muitos adquirirem algum dinheiro, mesmo quando escravizados; enfim eles nắo sảo incapazes de afeicilo e generusidade. A negra do administrador falou-me, de modo tocante, de seu amor filial; meus filhos, disse-me, nāo precisam mais de mim, mas nầ há um dia em que eu năo sinta saudades de minha mane, por isso chorando. Meu patrăo diz algumas vezes que deixarí esta regiăo e seguirá para o lugar onde ela estí. Tenho mandado rezar diversas missa.5 a Nossa Senhora da Aparecida para que ele realize boas intençūes. - $\mathrm{O}$ negro é apreciado com as suas forças morais, com o sentido psicológico de sta generosidade $e$ afeiço $\mathrm{e}$, principalmente, com aquela concepçáo de futuro que o torna de fato superior ao indio. Define-se, desta maneira, a personulidade do homem preto através de graus marcantes da vida interior.

Uma pequena ocorrẻncia, as sair da estincia de Coiova, fez o viajante francés deduzir do interesse pouco lisonjeiro dos negros quando esperam favores por obséquio comum. Retardando a partida, dois negros explicaram ạ sibio que estiveram ocupados a abater uma vaca, c ofereceram, entáo, um pedaço de came, dando-lhe de bom grado grande naco e nīo quiseram aceitar retribuiçāo em dinheiro. Devo esse obséquio, creio, conclui of francès, ao fato de saber minhas ligaçóes com o Conde, de quem esperam receber alguma graça.. Mas essa ardilosidade é justamente uma característica do africano. Ser astuto, afinal, revela inteligência. E os brancos muito se gabavam de revelar manhas...

Uma das mais poderosas razóes da cilma com que se operam as insurreiçōes aeste país, é que, principalmente nesta Capitania, nāo existe praticamente o que se chnma populaçăo, e quando existe ć pouco numerosa. Os negros que a representam sio muito distanciados dos homens livres e por demais subservientes, para se meterem nessas coisas - escreve Saint-Hilitire.

Nas estancias desta regiẫo, quase puramente pastoril, nâo săo precisos tâo numerosos escravos como acontece nas regiỏes açucareiras ou na exploraçăo dos minérios. Cerca de oitenta negros, apenas, ocupamse da construção do cortume e depois nele trabalharão. Quase todos os escravos do barão sió negros-minas, tribo bem superior a todas as outras, por sua inteligência, fidelidade e amor no trabalho - diz Saint-Hilaire. Refere-se ele, aqui, ao Bario de Santo Amaro, fazendeiro José Egidio, ex-secretário do conde de Barca e conselheiro do rei. A estância se denominava Boa Vista e erat uma das mais importantes da Capitania.

$\mathrm{Na}$ fazenda, o preto era ainda empregado nos misteres de copeiro, cabendo-lbe o cuidado do mate, servir a mesa e os bóspedes. Competia, 
em resumo, ao negro todo cuidado doméstico e ser o mantedor da vida da fazenda.

Nas charqueadas os negros são tratados com rudeza. $\mathrm{O}$ sr. Chaves tido como um dos charqueadores mais humanos, só fala aos seus escravos com exagerada severidade, no que 6 incitado por sua mulher; os escravos parecem tremer diante de seus donos - informa o ilustre naturalista. $O$ proletariado das casas de salgar carnes foi o mais sacrificado da democracia campesina. Inicio do período industrial, $\mathrm{e}$ a coletividade trabalhista oferecia um aspecto de volume, grandeza, que apenas poderia ser denominada pela energia, entâo, sinônimo de chicote, hoje com as devidas proporçōes, diz-se lei social. $O$ consolo dos negros era a religiăo, abundante em deuses amáveis, sensuais tâo ao agrado de suas almas. Simbioses das quais resultariam os devotos de $\mathrm{N}^{\mathrm{i}} \mathrm{S}^{a}$ do Rosário, de $\mathrm{N}^{\mathrm{T}}$ $S^{7}$ dos Navegantes e de São José e Sắo Benedito. As confrarias afro-católicas tinham um papel de forcas moderadoras.

Diversos conceitos:

Primeiro: os negros sào os mais valentes soldados de Artigas. Segando: sầ superiores em coragem ao indio. Terceiro: parte de sua bravura reside na esperança de libertação.

$\mathrm{Na}$ estància do Souza, na regiăo de São Borja, vizinha Entre Rios, quando ali se encontrava o ilustre francés, ocorreu um pequeno incidente que pós à mostra os subterfúgios nos quais sāo férteis os negros.

Um soldado e um guarani vieram de Entre Rios prender um preto, que praticara vários furtos naquelas redondezas, mas depois de executarem a diligência, no dia seguinte, sẫo encontraram o africano. Tỉnha fugido. Saini-Hilaire pouca significação dí ao caso. Ele mesmo diz que - nāo teria interesse esse fato sem importância, se năo fosse a circunslância do soldado, encarregado de capturar um ladrāo, ter-se feito acompanhar de sua mulher - reminiscéncia do hábito indio.

Nāo iremos desprezar, nós que temos que exumar as mais vagas palavrils sobre o preto, cultura quase secreta no Rio Grande, uma notícia reveladorir da capacidade mais inferior do negro... Ele bem sabia o que the estava reservado ao voltar...

Năo lá quem não tenha observado que os negros crioulos são muito menos distanciados de nós que os da costa da África. Pode-se atribuir ì educação e superioridade que mostram em relação à inteligência, mas ao mesmo tempo eles sâo de um negro mais escuro, sua testa ế menos arredondada, seus lábios menos grosseo, seu nariz menos chato; enfim năo há pessoa que, com pouco de prática, nāo saiba distinguir um negro 
crioulo de um africano.-Săo essas as pałavras do viajante europeu sobre o tipo diferencial do afro-brasileiro que surgiu das caldeaçóes mais diversas.

O viajante francês chegando ao Rio Grande, núcleo de primeira ofdem da capitania, năo encontrou água doce ou, por outra, iam procurá-lo atrás da cidade, entre monticulos de areia onde tinham sido feitos poços de pequenz profundidade.

Os negros vio buscí-la em barris, apanhando-a por meio de chifres de bois amarrados à ponto de varas compridas.

Outra funçío do preto: servir de condutor de água para a populaçấo. Elementos poderosos da economia urbana.

Em Santa Maria, um fazendeiro com 1.000 cabeças de gado nāo é homem rico, observa Saint-Hilaire mas mesmo assim os negros cuidam da plantaçio e a familia do proprietário dedica-se à vida pastoril.

O sábio francếs escandalizado com as danças negras, chamou o batuque de indecente, sem mais rodeio. Contudo, também, acrescentava, que poderia dizer o mesmo das danças mais decentes e mais elegantes de Montevidéu. Danças que não tinham absolutamente a movimentaçăo e a rapidez das parisienses.. Tudo se reduz a uma marcha vagarosa acompanhada às vezes de atitudes muito sérias $\mathrm{e}$ algumas vezes muito indecorosas.

Ao dizer-se que o negro foi uma personagem do cenário agrícoli, temos mais essa afimaçáo de Saint-Hilaire: em uma das ruas do Rio Grande existe um pequeno mercado (quitanda) onde negros, acocorados, vendem bortaliças, tais como - couve, cebola, alface e laranjas.

O negro nẳo sóplantava. Vendia, também. Mas serí que se alimenta de couve, cebola, alface e laranjas? Naturalmente furtava para comer.

Diz Saint-Hilnire:- Tive já oportunidade de referit ao fato de serem vendidos aqui os negros imprestáveis dos habitantes do Rio de Janeiro; quando querem intimidar um negro ameaçam-no de enviá-lo para o Rio Grande. Entretanto não há, crejo, em todo o Brasil, lugar onde os. escravos sejam mais felizes que nesta capitania. Os senhores trabalham tanto quanto os escravos, mantêm-se próximos deles c, tratam-nos com menos desprezo. O escrawo come catne à vontade, nî́ó mal vestido, nẫ anda a pé e sua principal ocupaçấo consiste em galopar pelos campos, coisa mais sadia que fatigante. Enfim eles fazem sentir aos animais que os cercam uma superioridade consoladora de sua condiçăo baixa, elevando-se aos seus próprios olhos. 
O povoamento do Rio Grande do Sul, curiosamente processou-se de dentro para fora, do interior para a praia, com um único porto, ainda, de difícil acesso. Nio projetou sua influència a barra. Os outros pontos da costa permaneceram mínguados o nẫo atingiram a mais do que povoados de cultivo de cebola. Zona arenosa que destruia até o porto, o aglomerado mais importante e mesmo o menos importante apelou para o preto afim de năo morrer soterrado. Saint-Hilaire anota: - vi negros ocupados em desentrilhar os arredoces des casas de seus donos, os quaís me informaram serem obrigados a repetir incessantemente esse trabalho para proteçâo das casas - pois a oeste c a sudoeste areias de extrema fineza cansam a vista pelo seu colorido esbranquiçado, e formam montículos que vĩo até junto das casas situadas atrás da cidade, elevando-se fanto que ameaçam aterrar as construçóes.

A Saint-Hilaire nilo escapou a visāo que distingue o negro da estîncia do negro da charqueadil.

Afirmei, diz ele, nesta Capitania, os negros sâo tratados com bondade e que os brancos com cles se familiarizaram, mais que em outro ponto do país. Referia-me ås escravos das estáncias, que sāo em pequeno numero; mas nas charqueadas a coisa muda de figura, porque sendo os negros em grande número e cheios de vícios, trazidos da capital, torna-se necessírio tratílos com mais energia.

Hâ mais de cem anos Saint-Hilaire pintavat um quadro assim:

- Sempre na sala há um pequeno negro de 10 a 12 anos, cuja função é it chamar os outros escravos, servir agua e prestir pequenos serviços caseiros. Nāo conheço criatura mais infeliz que essa criança. Nunca se assenta, jamais sorri, em tempo algum brinca! Passa a vida tristemente encostado à parede e é frequientemente maliratado pelos fillhos do dono. A noite chega-the o sono, e, quando nạo há ninguém ma sala, cai de joelhos para poder dormir. Nāo é esta casa a única que usa este impiedoso sistema; é frequiente em outras.

O negro na estância, entretanto, possuía quase as mesmas regalias de seus senhores, pelo menos, o stand de vida de ambos era semelhante, numa certa passagem parei, informa Saint-Hilaire, $\mathrm{em}$ uma estancia que se compóe de miserável palhoça, aberta, e de algumas casas de negro. Revela desta maneira como habitavam brancos o africanos. A planície sugeria apenas um horizonte, Saint-Hilaire por cssa ocasião ainda observa que uma viúva estancicira, a quem fora pedir um favor, cncontrava-se a fuar la para ponches grosseiros de negros. Ponches que os brancos também usavam como cheripá. A pequena mimufatura nascia nas casas dos proprietínios de terra, e latifundiários mais modestos, ùs vezes os 
ricos também, eram os artifices tecelōes do rudimentar trajo do preto. Reflexos da parcimônin lusitana on da falta de vendedores do que se necessitava.

Saint-Hilaire dấ o seu testemunho quando no Chui: - Após o almoço despedi-me do capitâo Manocl Joaquim de Carvalho, de quem hauri toda sorte de gentilezas, e que me acompanhou, a cavalo, até as margens do rio Sâo Miguel. Esse homem era apenas um mero soldado, mas fez tais prodigios de valor que, em uma regiăo onde quase só há brancos, guindanam-no apesar de sua cor, au posto capitaís.

Sobre o triângulo racial branco, indio e negro, o sábio francês emitira, com frequiência, muitos conceitos de paralelo assim como nestas quatro frases:- Os brancos sāo ingratos porque reconhecer um beneficio é confessar inferioridade, o que fere o amor próprio, mas essa ingratidăo e tardia e nunca vem no mesmo dia do beneficio usufruido. Os negros escravos podem ser gratos porque nada thes custa reconhecer a sua inferioridade e potque nunca esquecem o passado. Quanto aos índios não digo que esqueçam mas aão tiram conclusōes sobre o futuro, que é para eles, o que os sonhos ș̃o para nós, lembramos muito deles mas lebramos sem utilidade. $\widehat{E}$ pois difícil sejam os indios reconhecidos porque para isso é preciso tirar conclasóes do passado para o presente.

O negro para Saint-Hilaire, sempre foi saperior ao indio e ao naturalista năo escipava a significação do sentimento religioso, que no africano era muito mais intenso do que no aborigene.

Parando era Cachocina, no Botucari, estranhou o vinjante francês nắo possuírem negros os fazendeires.

Falitva o naturalista it tespeito da província das Missóes, que explicaram, entīo da seguinte maneira: - Serem a isso forçados, alugat peóes a oito e doze patacas por més, em vez de possuirem negros pondo- 0 s em perdiçăo.

Saint-Hilaire encontrou, próximo de Santa Maria, uma mãe preta que rezava para Nossa Senhora Aparecida a fim de que obtivesse a graça de, novamente, momr perto de seu filho. Era jă grande ofilho mas a negra velha descjava viver perto dele. Toda a dedicaçâo de negro náo era apenas imposta pelo senhor.

Os terriveis castigos impostos aos escravos, pelos senhores, deixavam, na sociedade da época, uma fisionomia de pavor.

Saint-Hilaire, mesmo diz que - os brasileiros sấo em geral prestimosos e generosos, mas o hábito de castigar os escravos embota-lhes a sensibilidade. 
Uma cena que Saint-Hilaire presenciou nas margens do Jacui, antes de Santo Amaro, mostra qualquer coisa de granítico ma alma do escravocrata.

Opatrî̉omandou seus camaradas içar o corpo de um de seus aegros, que se afogara quando o barco estava em Rio Pardo.

Quando avistamos o cadáver desse infeliz, o patrão gritou: $\mathrm{Ah}$, meu dinheiro! Meu dinheirot Oue me custa tanto a ganhar - Sua mulher foi, em uma piroga, presidir o enterro do corpo; sobre a sepultura foi fincada umi cruz de bambu. Quando a mulher regressou ao barco, estava banhada em lágrimas, mas a rudeza com a qual trata os escravos, fez-me crer que nilo chorava outra coisa senío seu dinheiro.

$O$ viajante francês atesta, no seu livro, os mais estrunhos e pesados trabalhos cometidos ao negro.

Tripulando pequenos bareos, os pretos remadores forçudos puxavam a reboque embarcaçốes à vela em dias de vento contrário. Espetáculo comum, no Jacuí ou no Uruguai, pobres africanos, conduzindo senhores e mercadorias preciosas.

Próximo a cjade do Rio Grande, o viajante francés depara com uma granja típica de açoriano. Vivendo numa palhoģa o proprietátio mas seu pomar ế extremameate bem cuidado e um dos maiores que o naturalista viu no Brasil.

É de notar que para cuidar desse pomar, ele, o dono emprega doze negros; certamente trés jardineiros cultivariam muito melhor um espaço de terreno semelhante e conclui a observaçấo: Os negros sầ naturalmente pouco ativos: quando livres só trabalham mal e com excessiva lentidăo.

Os dois estados do trabalho negro: livre e escravo.

Saint-Hilaire é indispensâvel ao ensaista brasileiro. O negro devethe paginas cruéis e simpáticas mas, acima de tudo, verdadeiras. Diante de seu livro de viagem, o estudioso poderí atender os mais originais, sutis e preciosos conceitos de graça, psicologia, saúde, clima, agricultura, economia e sociedade.

Nicolau Dreys, foi cronista honesto, e singelo.

Dreys, referindo-se ao nosso negro, diz:

"... o negro é um bom soldado e talvez seja esta a única profissão para que ele é naturalmente próprio. Um amigo nosso, oficial superior da República Argentína, chamava os negros - Suíços da América - em feferência ì suas disposiçôes guerreiras".

Havia ainda uma circunstaincia, como nos diz Nicolau Dreys, na sua "Noticia descritiva da Província de Sạo Pedro": o preço inferior do escravo adquirido para o Rio Grande: 
"De tempo muito remoto, quase desde a sua descoberta, o Rio Grande tem sido considerado como uma espécie de purgatório dos negros; até a explosão da guerra civil, quando um negro das outras províncias do Brasil manifestava alguma disposição viciosa, Rio Grande era o destino que se lhe infligia como um castigo; e ainda há pouco, quase todos os dias, os periódicos da corte ofereciam negros para vender, com a condição expressa de serem exportados para o Rio Grande".

$\mathrm{O}$ aparecimento da agricultura e o desenvolvimento das charqueadas encontraram no negro o trabalhador barato e rendoso.

O que, naturalmente, tornava o Rio Grande assustador era a manutenção da fronteira portuguesa.

As incursões platinas arrasavam os domínios particulares, e os proprietários rurais não encontravam para segurança de seus bens de campo senão o negro, que morreria facilmente na defesa do senhor.

$\mathrm{O}$ ambiente belicoso inspirava terror, porque aos negros, eles o sabiam, não era dado senão perderem a vida em favor de seus donos.

Entretanto, como anota, Nicolau Dreys: os negros das charqueadas do Rio Grande do Sul são bem alimentados e bem tratados pelos seus senhores, que só lhes aplicavam os castigos merecidos.

Quando se quis dar maior expansão à nossa agricultura, seguindo o exemplo do norte, começou a entrar o colono alemão, imigrante de 1824.

Os grandes períodos do trabalho braçal dos escravos negros, que sustentavam a integridade econômica do Império, não se refletiram em nosso ambiente com aquela mesma intensidade dos engenhos de açúcar, das lavouras de fumo, das plantações de algodão ou dos cafezais paulistas.

Porque o trabalho do negro foi substituído entre nós de início pelo braço alemão.

Arsène Isabelle levou suas impressões num livro intitulado "Viagem a Buenos Aires e Porto Alegre, pela Banda Oriental, Missões do Uruguai e a Província do Rio Grande do Sul, seguida de consideraçóes sobre o estado do comércio exterior francês, e principalmente para o Brasil e o Rio da Prata".

O período da viagem é de 1830 a 1834 , quatro anos portanto, e sua visita ao sul do Brasil começa nos fins de 1833 e e decorre durante todo $o$ ano seguinte.

Vamos deixar o estudo crítico da obra de Isabelle, seu amadorismo literário, defeitos e injustiças, para extrair de seu livro algumas notícias sobre o negro no Rio Grande do Sul. 
Náo fe muita coísa, mas sempre uma dúzia de observaçōes se consegue,

Passando a fronteira argentino-brasileira, ao sproximar-se de Alegrete no Rio Grande do Sul, já Isabelle ial em direção ao centro da província; fala de como eslava organizada sua caruvana: "afora os dois companheiros $\mathrm{c} \mathrm{eu}$, dizia Isabelle, o pessoal se compunha do tropeiro, quatro arreadores, sendo dois negros $\mathrm{e} \mathrm{um} \mathrm{indio;} \mathrm{o} \mathrm{capataz} \mathrm{e} \mathrm{um} \mathrm{picador}$ (ou arreador) eram brasileiros. Caminhãxamos ora a cavalo, ora a pé ou de carreta.

"Os negros de Porto Alegre venden, por quase nada, belas peles, assim como bugios. Se os negros vendem por quase nada é porque vendem por sua conta, senăo se fossem apenas encarregados pelos brancos, entäo os preços naturalmente seriam outros.

Todo mundo comia no mesmo prato, escreve desolado e acrescenta: "nío bebíamos nuncia comendo, mas depois da refeição um negro trazía um chifre cheio d'água na roda, e cada um bebia por sua vez".

Agora Isabelle está no Rio Pardo, "cidade* importante, muito povoada, e observando as comunicaçées fluviais grande número de barcos diz: "Partem e chegam constantemente, tem-se a certeza de ser transportado com rapidez, porque, quando o vento nio é favoríivel quatro ou cinco negros nús remam sem parar dia e noite".

É uma regata violenta, mas os negros estâo nús, maneira conum de andarem eles por essa época.

Como escrives eles tinham que fazer os trabalhos mais pesades ou de toda espécie de trabalho.

Ao chegar enı Porto Alegre, vê Isabelle que "os fardos, qualquer peso que tenham, sảo transportados pelos negros no pátio da alfî̀ndega para serem vistoriados; ai outros negros (porgue at raça iffricana tem no Brasil a profissão de cavalos e mula) os transportam para o seu destino".

O negro, carregador do cais e do trapiche, mi rua, nas casas, servindo de guindaste e de carroça.

Isabelle desabafa e solta improperios terriveis contra a exploraçẫo do negro náo só contra os da terra, como contra es colonos europeus, na América, mas essa ma literatura agota nào nos interessa.

Mais adiante em Porto Alegre, Isabelle anota: "Aqui, como em todas as antigas possessôes espanholas e portuguesas, os negros e mulatos sấo operíitios, quer dizer, homent laboriosos, trabalhadores, aqueles que enfim tem necessidade de usar mais a sua inteligéncia, mas tem a desgraça de serem escravos e, sobretudo de serem negros". 
Não escapou ao atilado viajante francês que aos escravos negros se tinham dado todos os ofícios e as pequenas atividades artísticas no Brasil e que Porto Alegre, como no Brasil e na América, o negro era operário e artífice, o único, o mais produtivo e o mais explorado.

Isabelle não se contém e aproveita para escrever uma catilinária em regra contra os senhores de escravos.

Descreve então os castigos de negros que presenciou em Porto Alegre, no ano da graça de 1834 , com estas palavras: "Cada dia, das sete às oito horas da manhã, pode-se assistir em Porto Alegre, a um drama sangrento, ponto de reunião na praia, ao lado do arsenal, de fronte da Igreja, diante do instrumento de suplício do divino legislador, vereis uma coluna erguida num maciço de alvenaria e ao pé... uma massa informe, alguma, coisa certamente pertencente ao reino animal que não podeis classificar entre humanos bípedes... é um negro"!

E adiante, menos patético, mas mais preciso: "Um negro condenado a duzentas, quinhentas, mil, seis mil fustigadas de relho".

"Como tratamos nossos cães", esclarece sem subterfúgios Isabelle. "Começam mesmo por assobiar, e se eles (negros) não vem imediatamente, recebem duas ou três bofetadas da mão delicada metamorfoseada em mulher-víbora"...

A narrativa sobre os castigos continua: se o negro não apanha da senhora leva ponta-pés e socos do amo ou então é espancado pelos dois: o senhor e a senhora.

Mas se o infeliz, resmunga, fala entre dentes, é então atado no primeiro poste, naturalmente há em toda a parte vários com esse fim, e o negro termina surrado até derramar sangue.

"O senhor e a senhora vem, com grande alegria no coração", assistir ao flagelo daqueles, diz Isabelle, "que apenas cometeram o erro bem inocente de não ter sabido adivinhar os caprichos de seus senhores e patrōes!"

Insiste nos detalhes dos castigos de negros: os senhores e senhoras de escravos armados de relho, pau, barra de ferro ou corda, surrando negro até levantar a carne então lavada em sangue, lugar onde depois mandavam botar sal com pimenta para curar as feridas, assim como se tratavam os vermes e bicheiras dos animais.

"Vi mais ainda, diz, há senhoras assaz bárbaras, principalmente no campo para fazerem incisôes nas faces, espáduas, nádegas, coxas de seus escravos, a fim apenas colocar pimenta".

Assegura que outros senhores de escravos levam seu furor frenético até o ponto de assassiná-los. 
Disso nầ guardam o menor remorso, além de atirarem o negro numa cova como se fosse um cachorro; quando se perguntava por esse escravo đesaparecido, respondiam com a maior sem-cerimônia, naturalmente acompanhado de gestros e palavras pornográficos, que o negro morreu e estava, então tudo acabado.

lsabelle, desolado com todos esses vícios e crueldade de uma sociedade escravista, reconbece que existe uma lei mandando punir senhor assassino de escravos, mas a lei năo é para os fortes, conclui entristecido o viajante, que saira do Havre para ver todas essas misérias da escravidằo.

Termina Arsène Isabelle seu livro com mais uma referência somente, sendo que agora é para dizer que "Feitoria", lugar situado nos arredores de Porto Alegre, tinha esse nome porque ali antigamente se vendiam eseravos.

Este costume de beber somente depois de ter comido, é geral no meio das tribos indigenas de todo o Brasil, Paraguai e Buenos Aires.

Aí está o negro desempenhando, como eseravo, a funçăo de criado. Escravo está evidente que é o negro, pois o indio teve uma referểncia à parte.

No papel de criado, sua posiçẩo é mais humanizada, uma vez que ele bebe no mesmo chifre que serviu de copo para o seu senhor, o que não é pouco, quando as concessūes ao negros eram lāo restritas.

Foram essas as ùnicas citaçôes de negros escravos que Isabelle fez ao passar pelosul do Brasil, citaçóes interessantes para o estudo de alguns aspectos da história do negro no Rio Grande do Sul.

\section{VI-Pesquisas}

O presente estudo, simples conferência, nāo inclui, para manter as proporçóes de um trabalho deste gênero, os seguintes problemas:

- Aspecto Filológico

- Aspecto Económico

- Aspecto Jutídico

- Aspecto Sociológico, etc.

Também não foram nem sequer examinadas as diversas posiçôes: cientificas das numerosas e importantes escolas antropológicas ou etnográficas estrangeiras, tais como algumas que sỉo as enumeradas abaixo: 
-Franz Boaz (1859-1942) prof, da Universidade de Columbia, em New York, $c$ a Escola Norte-Americana;

- Leo Frobenius, Prof da Universidade de Frankfurt sobre o Meno, e a Escola Alemä;

- Mendes Corrê2, prof. da Universidade do Porto, e a Escola Portuguesa;

- Sir James George Frazer e a Escola Inglesa;

- Maurice Delafosse e a Escola Francesa; Théodore Monod e o Instituto Française d'Afrique Noire.

Nào aparece a literatura de outros países com interesse na África: Bélgica, Holanda, Espanha, Itálía, cte.

Evidente, que se poderia levantar uma bibliografia estrangeira sobre "africanologia" mas nīo é este o propósito que nos levou a um estudo generalizado e superficial de história apenas regional. As cilaçoes dos autores devem ser completadas, o que nito se fez. As escolas por sua vez sāo apenas uma afirmaçîio que necessita ser desenvolvida.

Notar-se-á, tambem, a falta dos nomes brasileiros.

Deve-se a Gilberto Freyre a valorizaçào e o renascimento cientifico do exame do problema do negro. Antes do "mestre de Apipucos", lugar onde ele vive, na sua cidade natal, nào se cogitava de uma análise erudita do assunto c o caso estava relegado a modesto segundo plano. De modo que ele é tealmente figura central.

Salientem-se, no pais, ainda o seguinte:

- Congressos Afro-Brisileitos (3),

- Estudos baianos,

- Estudos mineiros,

- Estudos pernambucanos.

- Mario de Andrade, o grupo de S. Paulo Paulo, Faculdade de Filosofia e a Escola de Sociologia. Roger Bastide, Rossini Tavares de Lima, Donald Pierson, Mário Wagner, Otávio Eduardo, etc.

- Arthur Ramos e a Faculdade Nacional de Filosofia. A antiga Universidade do Distrito Federal.

Investigạ̧ōes no Maranhtio, Alagoas e Rio Grande do Norte. Théo Brandăo.

- A religiăo, Edison Cameiro e a nova geraçāo. Os inquéritos de Gonçalves Fernandes.

- Aires de Mata Machado, Jolo Dorras Filho e Nelson de Sena; a história e a fllologia.

- Os precursores e Joắo Ribeiro.

- A linguagem: Renato de Mendonça Jacques Raymundo. 
- A pesquisa nos diversos camposi Sociologia. Antropología, Etnografia, etc.: - Renato Almeida e a Comissão Nacional de Folclore; - Luiz da Camara Cascudo.

- Estudes gaúctuos. Apolinário Porto Alegre, Alfredo Varela c Aurćlio Porto. A pesquisa monogrăfica, os trabathos atuais. Enio de Freitas e Castro e as congadas. Comissito Sal Riograndense de Folelore.

Finalmente, encerro esta räpida e falla relaçāo para destacar a obra de grandes pesquisadores atuais, especialistas em temas africanos, que estiveram no Rio Grande do Sul.

- Gilberto Freyre - ilustre sociólogo brasileiro esteve duas vezes no Rio Grande do Sul. Escreveu diversos trabalhos na imprensa do país e aludiu à influência africana no nosso estado. Publicou dois notáveis ensaios: "Continente e Ilha" e "Sugestöes para o estudo bistórico-social do sobrado no Rio Grande do Sul", ambos os trabalbos, como se vem, estìo dedicados à Provincia de Sảo Pedto.

- Melville Jacobs Herkovits - Sábio norte-americuno, nascido em Ohio no ano de 1895 e desde 1927 professior de antropalogia na Norwestern University, Evanston, arredores de Chigago. Em 1924, inicion famosas pesquisas antropofétricas do negro norte-americano.

Realizou investigaçōes referentes ao negro no Dahomey, Guiana Holandesa, Trinidad, Haìti e Bahia. M. Francis Herskovits, sua csposa, colabora com ele. Esteve no Rio Grande do Sul e publicou suas observaçōes sobre o negro aqui: "Extremo Sul dos Africanismos no Novo Mundo". Pesquisa notável, traduzida pelo Prof. Elpidio Ferreira Paes e publicada nos Anais da Faculdade Catolica de Filosofia, em 1943.

- Roger Bastide - sociólogo francês que lecionou muitos anos na Faculdade de Fílosofia, Ciências e Letras da Universidade de Säo Paulo. O distinto mestre da Sorbonne estudou, no nosso pais, o problenta do negro, escrevendo livros e monografias indispensâveis pela sua importância $e$ originalidade.

Esteve, no Rio Grande do Sul, e publicou suas observaçôes sobre o negro gańcho num trabalho intitulado: "Le Batuque de Porto Alegre", que apresentou ao $29^{\circ}$ Congresso Internacional de Americanismo, reunido em 1952 nos Estados Unidos.

As trés eminentes mutoridades - Gilberto Freyre, Melville J. Herskovits e Roger Bastide - atestaram a existência do negro sul-rio-grandense.

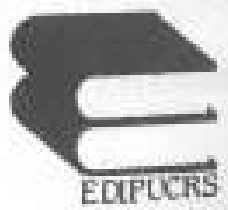

